\title{
The nitrogen-sparing effect of methionine sulphoxide and some other sulphur-containing amino acids
}

\author{
BY L. R. NJAA AND A. AKSNES \\ Government Vitamin Institute, Directorate of Fisheries, 5013 Bergen, Norway
}

(Received 1 February 1982 - Accepted 21 June 1982)

\begin{abstract}
1. The nitrogen-sparing effect of methionine, methionine sulphoxide, homocystine, cystine and choline was studied in rats by determining daily $\mathrm{N}$ excretions during $5 \mathrm{~d}$ after changing from a high-protein diet to a protein-free diet. L-glutamic acid was used as a negative control.

2. L-, D- and DL-methionine were equally active in sparing N. L-methionine sulphoxide, DL-homocystine and L-cystine were as active as L-methionine. D-methionine sulphoxide was slightly less active than L-methionine sulphoxide. Choline hydrogen tartrate was not different from the negative control.

3. It is concluded that in short-term experiments cystine is the key substance in the $\mathrm{N}$-sparing effect.
\end{abstract}

The question of whether methionine sulphoxide is biologically available as a methionine source for rats and other experimental animals is a matter of some controversy (Gjøen \& Njaa, 1977). In the present study we have tested whether the sulphoxide has a nitrogen-sparing effect (Dreyer, 1970) similar to that reported for methionine in experiments with rats, dogs, pigs and chicks (Nielsen et al. 1939; Miller, 1944; Allison et al. 1947; Brush et al. 1947; Muramatsu \& Okumura, 1980).

The $\mathrm{N}$-sparing effect is observed when the experimental animals are given methionine in small amounts in an otherwise protein-free diet. The urinary $\mathrm{N}$ excretion is then reduced as compared to that seen without the methionine addition. The effect is most pronounced early after changing from a protein-containing to a protein-free diet (Miller, 1944; Dreyer, 1970; Lubaszewska et al. 1973).

We have studied the urinary $\mathrm{N}$ excretion during $5 \mathrm{~d}$ after changing rats from a stock diet containing approximately $240 \mathrm{~g}$ protein $/ \mathrm{kg}$ to a protein-free diet to which the amino acids under study were added. The amino acids tested were L-, D- and DL-methionine, L- and D-methionine sulphoxide, L-cystine, DL-homocystine and L-glutamic acid; choline hydrogen tartrate was also tested.

\section{METHODS}

Analytical procedures

Urine was collected as described by Njaa (1963). $\mathrm{N}$ in the daily urine samples was determined essentially as described by Crooke \& Simpson (1971). In Expt 6 urea was determined as described by Potts (1967) omitting the extraction procedure. The results were analysed by analyses of variance and comparisons between treatments were done after partitioning the treatment sum of squares into single degrees of freedom as described by Snedecor (1956).

\section{Experimental procedures}

Six experiments were performed. Each experiment comprised three or four experimental groups of five or six rats, all experiments, except Expt 1, were run with litter mate controls. The rats used were males which had been given the stock diet for at least 2 weeks before they were given the experimental diets. The latter consisted of a protein-free diet to which were added the amino acids tested. The composition of the protein-free diet was $(\mathrm{g} / \mathrm{kg}$ diet): partially-dextrinized potato starch 680 , sucrose 200 , arachis oil 60 , mineral mixture 40 , 
Table 1. Design of experiments and amounts of amino acids or choline hydrogen tartrate added $(\mathrm{g} / \mathrm{kg})$ to the protein-free diet

(Numbers in parentheses indicate the group no. in the experiments)

\begin{tabular}{|c|c|c|c|c|c|c|}
\hline Expt no. . & 1 & 2 & 3 & 4 & 5 & 6 \\
\hline L-Methionine & $3 \cdot 2(1)$ & - & $3 \cdot 2(1)$ & $3 \cdot 2(1)$ & $3 \cdot 2(1)$ & $3 \cdot 2(1)$ \\
\hline D-Methionine & - & - & $3 \cdot 2(2)$ & - & - & - \\
\hline DL-Methionine & - & - & $3 \cdot 2(3)$ & - & -. & - \\
\hline L-Methionine & $3 \cdot 5(2)$ & $3 \cdot 5 \quad(1)$ & - & $3 \cdot 5(2)$ & - & - \\
\hline sulphoxide & $2 \cdot 6(3)$ & $1.75(2)$ & - & - & - & - \\
\hline $\begin{array}{l}\text { D-Methionine } \\
\text { sulphoxide }\end{array}$ & - & - & - & $3 \cdot 5(3)$ & - & - \\
\hline L-Cystine & $0 \cdot 6(3)$ & - & - & - & - & $2 \cdot 6(2)$ \\
\hline DL-Homocystine & - & - & - & - & $2 \cdot 9(2)$ & - \\
\hline $\begin{array}{l}\text { Choline hydrogen } \\
\text { tartrate }\end{array}$ & - & - & - & - & $\begin{array}{l}2.9(3) \\
1.8(3)\end{array}$ & $5 \cdot \overline{4(3)}$ \\
\hline L-Glutamic acid & $3 \cdot \overline{2}(4)$ & $\begin{array}{l}1 \cdot 75(2) \\
3.2(3)\end{array}$ & $3 \cdot \overline{2}(4)$ & $3 \cdot \overline{2}(4)$ & $3 \cdot \overline{2(4)}$ & $3 \cdot \overline{2}(4)$ \\
\hline
\end{tabular}

vitamin mixture 10 , cellulose powder 10 . The dietary levels of minerals and vitamins were as described by Gjøen \& $\mathrm{Njaa}$ (1977). The amount of $\mathrm{N}$ added to the diet from the amino acids was $300 \mathrm{mg} / \mathrm{kg}$ diet which is equivalent to $3.2 \mathrm{~g}$ methionine $/ \mathrm{kg}$ diet. Each rat was given $10 \mathrm{~g}$ food daily and a record was kept of food intake. The urine was collected daily from each rat and analysed separately for $\mathrm{N}$. The experiments lasted for $5 \mathrm{~d}$ and urine was collected from the first day.

The design of the experiments is shown in Table 1. L-glutamic acid was used as a negative control, and L-methionine as a positive control in all experiments except in Expt 2 where the positive control was omitted.

Expt 1. L-methionine, L-methionine sulphoxide and L-methionine sulphoxide (225 mg N/ $\mathrm{kg}$ diet) together with L-cystine $(75 \mathrm{mg} \mathrm{N} / \mathrm{kg}$ diet) were compared for their $\mathrm{N}$-sparing effect.

Expt 2. L-methionine sulphoxide $(300 \mathrm{mg} \mathrm{N} / \mathrm{kg}$ diet), and L-methionine sulphoxide $(150 \mathrm{mg} \mathrm{N} / \mathrm{kg}$ diet $)$ together with L-glutamic acid $(150 \mathrm{mg} \mathrm{N} / \mathrm{kg}$ diet $)$ were compared.

Expt 3. L-, D- and DL-methionine were compared.

Expt 4. L-methionine, L-methionine sulphoxide and D-methionine sulphoxide were compared.

Expt 5. L-methionine, DL-homocystine, and DL-homocystine together with choline were compared. The choline added could theoretically methylate $33 \%$ of the homocystine, bearing in mind that only one of its methyl groups is transferable. Thus, in the group receiving choline the level of added $\mathrm{N}$ was $400 \mathrm{mg} / \mathrm{kg}$ diet.

Expt 6. L-methionine, L-cystine and choline were compared at equivalent $\mathrm{N}$ levels.

\section{RESULTS}

The results obtained are summarized in Table 2 . They refer to the entire $5 \mathrm{~d}$ period. Similar tables for the separate days could have been presented, but as the results were rather clear-cut the daily excretions are only occasionally referred to.

In all experiments in which L-methionine and L-glutamic acid were compared the urinary $\mathrm{N}$ excretion was significantly less with the former. In most instances the difference was already highly significant on the second day of the experiment; in Expt 4, in which the individual variations were great, the difference was highly significant from day 3 . 


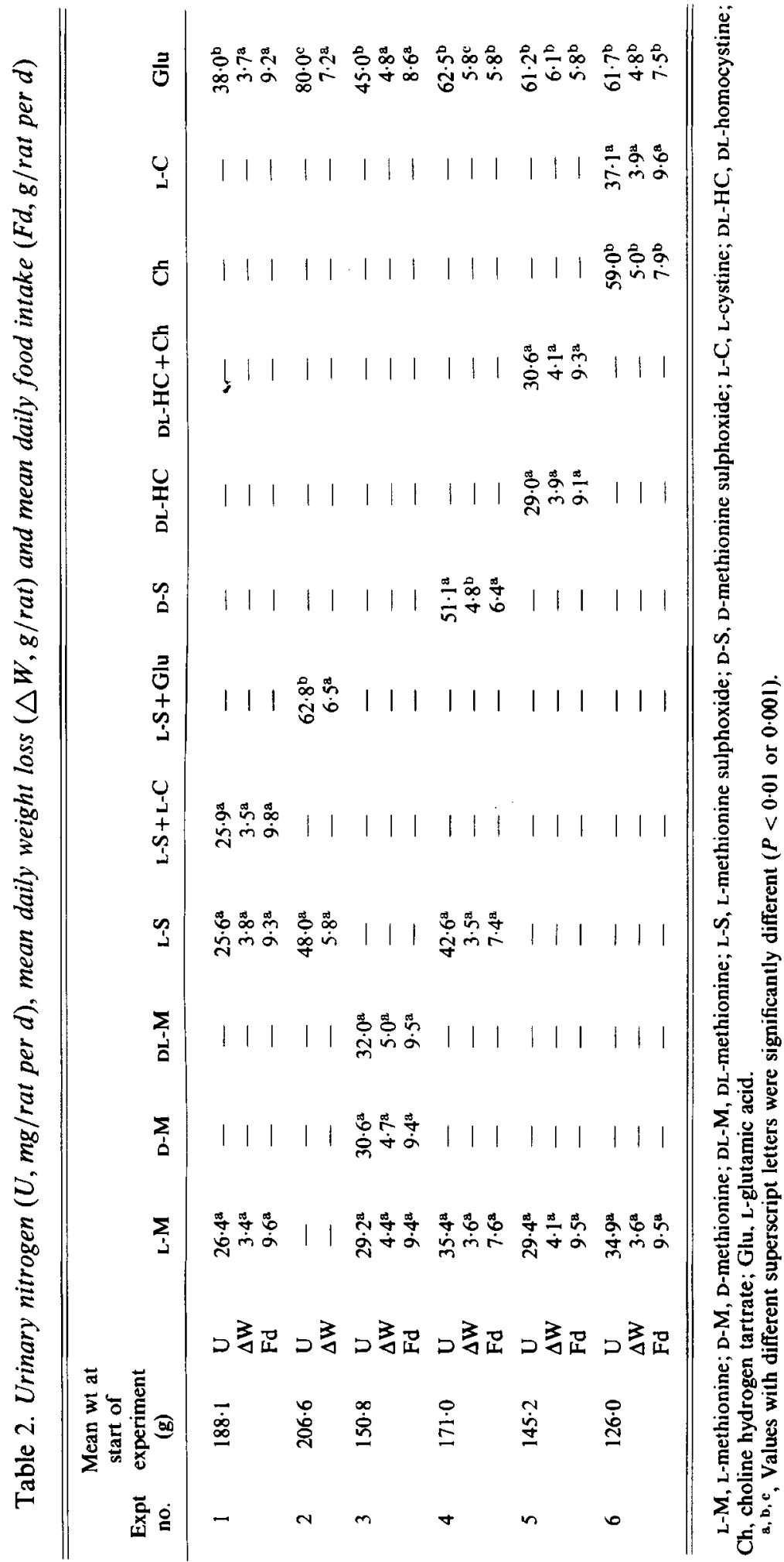




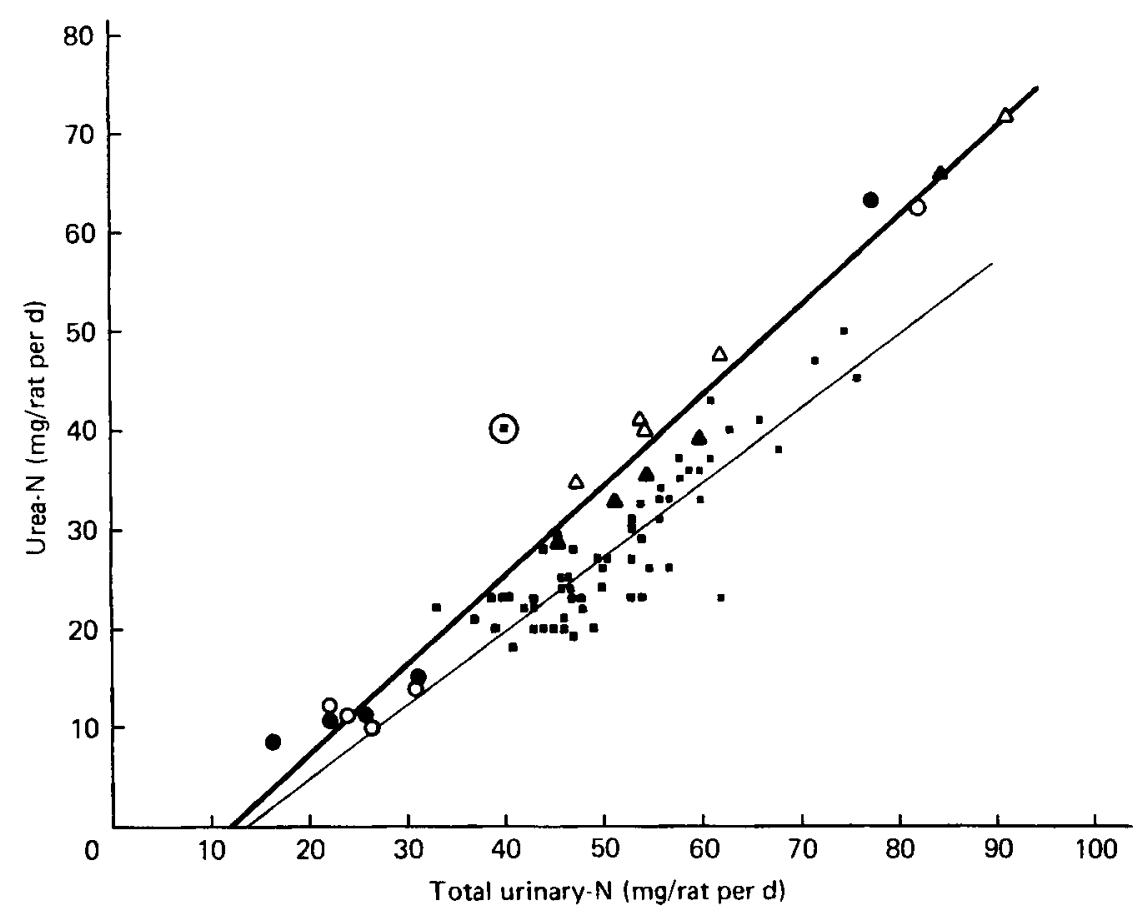

Fig. 1. Expt 6. Relationship between the daily excretions of total urinary nitrogen (TN) and urea-N (UN), and between values calculated from Lubaszewska et al. (1973). (O), L-methionine; (O), L-cystine; (A), choline hydrogen tartrate; $(\triangle)$, L-glutamic acid. $\mathrm{UN}=0.901 \mathrm{TN}-10.61, r+0.992, n 20$. (a), Lubaszewska et al. (1973). UN $=0.739 \mathrm{TN}-9.68, r+0.893, n 59$. (The circled value was not used in the calculation.)

The results obtained with L-methionine sulphoxide showed no significant difference from those obtained with methionine (Expt 1). This was also the situation when $250 \mathrm{mg}$ methionine sulphoxide-S/g was replaced by L-cystine-S. In Expt 4 there was a tendency for L-methionine sulphoxide to be less effective than L-methionine, and for D-methionine sulphoxide to be less effective than L-methionine sulphoxide. The differences were not significant when taken over the entire $5 \mathrm{~d}$ period. However, for the last $2 \mathrm{~d}$ the difference between $\mathrm{D}$-methionine sulphoxide on the one hand and L-methionine sulphoxide and L-methionine on the other was significant $(P<0.05)$ whereas the difference between the latter two was not. In Expt 2, L-methionine sulphoxide was tested at two levels. At the level equivalent to $3.2 \mathrm{~g}$ methionine $/ \mathrm{kg}$ diet the difference between the urinary $\mathrm{N}$ excretions on the L-glutamic acid diet and that on the sulphoxide diet was $32 \mathrm{mg} \mathrm{N} /$ rat per $\mathrm{d}$. When the sulphoxide level was halved the difference was also approximately halved to $17 \mathrm{mg} \mathrm{N} / \mathrm{rat}$ per d. In Expt 5 the effect of DL-homocystine was not significantly different from that of L-methionine and the addition of choline to the homocystine was without any additional effect.

In Expt 6 the effect of L-cystine was not significantly different from that of L-methionine, and the $\mathrm{N}$ excretion on the diet with added choline was not significantly different from that found on the diet with added L-glutamic acid. The urea-N content of the urine samples paralleled closely the total $\mathrm{N}$ content. The close linear correlation between the two variables is shown in Fig. 1. The mean weight losses and the mean food intakes showed significant differences in Expts 4-6, but not in Expts 1-3 (Table 2). 


\section{DISCUSSION}

Our main concern in these experiments was whether the $\mathrm{N}$-sparing effect of L-methionine was retained by L-methionine sulphoxide. This could be answered in the affirmative (Expts 1 and 4). There were, however, indications that $D$-methionine sulphoxide was less effective (Expt 4). The effect of L-methionine sulphoxide was dose related (Expt 2). As L-cystine and DL-homocystine were also as effective as L-methionine (Expts 2, 5 and 6) the $\mathrm{N}$-sparing effect seemed not to be due to the furnishing of labile methyl groups. Mudd (1980) pointed out that methylneogenesis is so controlled that labile methyl groups are made available to meet the needs for methionine. Moreover, choline showed no effect (Expts 5 and 6). The fact that L-, D- and DL-methionine as well as DL-homocystine were equally effective indicates that the configuration around the $\alpha$-carbon was of little importance (Expts 3, 5 and 6 ). The indication that $\mathrm{D}$-methionine sulphoxide was less effective than L-methionine sulphoxide could probably be interpreted to show some importance of the configuration around the sulphur atom. In an earlier communication it was shown in $\mathrm{N}$-balance experiments that D-methionine sulphoxide was less effective as a substitute for L-methionine than was L-methionine sulphoxide ( $\mathrm{Njaa}, 1962)$.

The finding that L-cystine had the same $\mathrm{N}$-sparing effect as L-methionine would indicate that cystine is the key substance in this connexion. Cystine is outside the reversible pathways of methione metabolism (Mudd, 1980). Assuming that a system exists for the reduction of methionine sulphoxide to methionine, cystine can be formed from all the substances found to show a $\mathrm{N}$-sparing effect but it cannot serve as a source for any of them. It may be relevant in this connexion that Finkelstein et al. (1980) suggested that trans-sulphuration, rather than methionine conservation, is a major metabolic response in hepatic regeneration. Also, the results with cystine obtained with dogs (Nielsen et al. 1939; Miller, 1944) and with rats (Brush et al. 1947) indicate that methionine itself is not necessary to obtain the $\mathrm{N}$-sparing effect.

During protein depletion the urine produced contains progressively less urea-N, both in absolute amounts and relative to total N (Dreyer, 1970; Lubaszewska et al. 1973). Our results confirm this. In Fig. 1 it is shown that we found a linear correlation between urea-N and total urinary $\mathrm{N}$ with a positive regression coefficient and a negative constant term. Thus, the regression equation is consistent with an absolute and a relative decrease in urea- $\mathrm{N}$ as total $\mathrm{N}$ excretion decreases. Fig. $\mathrm{l}$ also includes the regression line between urea-N and total urinary $\mathrm{N}$ calculated from the results of Lubaszewska et al. (1973). For the purpose of comparison with our results the observations were calculated as $\mathrm{mg} \mathrm{N} / \mathrm{rat}$ per $\mathrm{d}$ assuming a body-weight of the rats of $280 \mathrm{~g}$. The constant terms in the two equations were very similar. They may be interpreted to represent a relatively constant part of the urinary $\mathrm{N}$ excretion which is independent of the total loss. Together with a minimum obligatory loss of urea- $\mathrm{N}$ it would constitute the constant endogenous $\mathrm{N}$ loss. The fact that the regression coefficients were different may probably be a consequence of different experimental techniques. Lubaszewska et al. (1973) fasted their rats for $12 \mathrm{~h}$ before the start of the experiments whereas we took our rats directly from the stock diet to the protein-free diet. They also collected urine for five 3-d periods whereas we analysed the daily urines. Similar differences in technique are also obvious between our experiments and those of Dreyer (1970).

In our experiments we did not always find reduced body-weight losses in the groups of rats in which the $\mathrm{N}$-sparing effect was observed. This is in contrast to the findings of Yoshida $\&$ Moritoki (1974) and to later publications from the same group. However, our feeding periods were so short that the measurement of weight loss would be subject to great error. In Expts 4-6, in which significant differences were observed, the differences were in the expected direction and were accompanied by parallel differences between the food intakes.

The $\mathrm{N}$-sparing effect of methionine has tentatively been explained by assuming that it is needed for the production of an essential metabolite, and that the body raids its own 
tissue if this amino acid is not supplied by the diet (Hoover et al. 1949). The present study was aimed mainly at establishing whether methionine sulphoxide retained the $\mathrm{N}$-sparing effect of methionine. The experiments indicate that it does. Moreover, as it seems probable that cystine is the key substance in short-term experiments, reduction of methionine sulphoxide to methionine is indicated.

\section{REFERENCES}

Allison, J. B., Anderson, J. A. \& Seeley, R. D. (1947). J Nutr. 33, 361.

Brush, M., William, W. \& Swanson, P. P. (1947). J. Nutr. 33, 389.

Crooke, W. W. \& Simpson, W. E. (1971). J. Sci. Fd Agric. 22, 9.

Dreyer, J. J. (1970). S. Afr. med. J. 44, 336.

Finkelstein, J. D., Martin, J. J., Kyle, W. E. \& Harris, B. J. (1980). Proc. Soc. expl. biol. Med. $164,510$.

Gjøen, A. U. \& Njaa, L. R. (1977). Br. J. Nutr. 37, 93.

Hoover, C., Swanson, P. \& Stewart, H. M. (1949). Fedn Proc. Fedn Am. Socs exp. Biol. 8, 386.

Lubaszewska, S., Pastuszewska, B. \& Kielanowski, J. (1973). Z. Tierphysiol. Tierernähr. Futtermittelk. $31,120$.

Miller, L. L. (1944). J. biol. Chem. $152,603$.

Mudd, S. H. (1980). Ciba Fdn Symp. no. 72, p. 239.

Muramatsu, T. \& Okumura, J-I. (1980). J. Nutr. 110, 59.

Nielsen, E. K., Gerber, L. P. \& Corly, R. C. (1939). Am. J. Physiol. 126, 215.

Njaa, L. R. (1962). Br. J. Nutr. 16, 571.

Njaa, L. R. (1963). Rep. Tech. Res. Norwegian Fish Ind. no. 5, p. 118.

Potts, T. J. (1967). J. Ass. Off. analyt. Chem. 50, 56.

Snedecor, G. W. (1956). Statistical Methods Applied to Experiments in Agriculture and Biology, ch. 12, 5th ed. Ames, Iowa: The Iowa State College Press.

Yoshida, A. \& Moritoki, K. (1974). Nutr. Rep. int. 9, 159. 